\title{
Surface soil temperatures of various land cover types within the Chianan Plain, southern Taiwan
}

\author{
Wenfu Chen* \\ Institute of Hot Spring Industry, Chia Nan University and Science, Tainan City, Taiwan
}

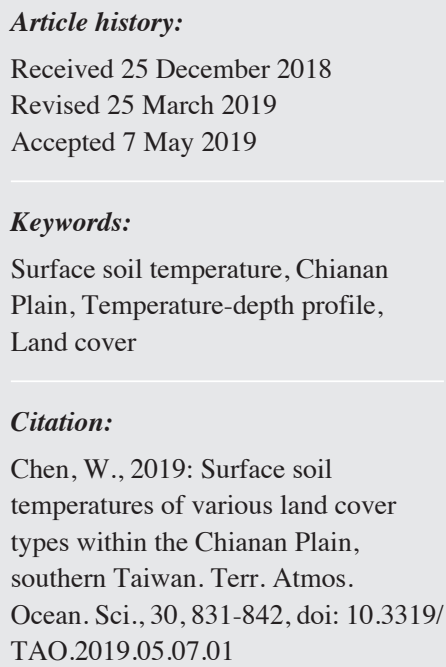

\begin{abstract}
Surface Soil Temperature (SST) is defined as the near-surface temperature of the ground that consists of the upper boundary of the subsurface temperature-depth curve. SST is an important parameter for understanding subsurface heat transfer and effects of climate change. However, to date, no studies have focused on SST, land use surrounding monitoring wells, and temperature-depth profiles within the Chianan Plain, southern Taiwan. Values for Measured Surface Soil Temperature (MSST) were in a range of 23.8 to $28.3^{\circ} \mathrm{C}$, higher than average annual air temperatures that ranged from 23.9 to $25.2^{\circ} \mathrm{C}$ within the Chianan Plain. Values of Present Surface Soil Temperature (PSST), which represent a long-term average, were 24.2 to $28.1^{\circ} \mathrm{C}$, as determined from temperature-depth profiles. Temperature of various land cover types were $24.9,25.6,25.6,26.5$, and $28.8^{\circ} \mathrm{C}$ for crops, trees, buildings, fish ponds, and bare soils, respectively. Temperatures for trees were lower than average while temperatures for bare soil without shielding were higher. Values of SST change displayed a warming trend with a maximum value of $4.11^{\circ} \mathrm{C}$ and $82 \%$ of sites fell into the range from 0 to $3^{\circ} \mathrm{C}$. The change in annual average air temperature due to global warming was 1 to $2^{\circ} \mathrm{C}$ from 1901 to 2015 . Causes for SST changes larger than $2^{\circ} \mathrm{C}$ should be attributed to land cover change in addition to global warming. This study provides the first basic dataset for MSST and temperature-depth profiles within the Chianan Plain. The data provided can be used as a base line for future studies of climate change, groundwater and subsurface temperature changes.
\end{abstract}

\section{INTRODUCTION}

Surface Soil Temperature (SST or Ground Surface Temperature, GST) is defined as the surface or near-surface temperature (soil, bedrock, or surficial deposits) measured in the uppermost centimeters of the ground (Smirnova et al. 1997; Shafer et al. 2000; Signorelli and Kohl 2004; Lundquist and Lott 2008; Holmes et al. 2012; Vargo et al. 2013). Physical models for determinations of SST depend on the surface energy of solar radiation, ground heat flux, and latent heat flux and sensible heat flux (Deardorff 1978; Herb et al. 2008; Leaf and Erell 2018). Previous studies indicated that SST variations significantly affected by different land cover types including pavement, bare soil, grass, trees, and agricultural crops. Asphalt and concrete pavements generally have the highest SST due to less latent heat flux, while

\footnotetext{
* Corresponding author

E-mail: chenwenfu@mail.cnu.edu.tw
}

SST under vegetated surfaces yield the lowest value attributed by high latent heat flux (Skinner and Majorowicz 1999; Herb et al. 2008).

SST is the temperature at the upper boundary of the subsurface temperature-depth profile, an important parameter for understanding subsurface heat transfer (Kupfersberger et al. 2017), groundwater recharge (Bense and Beltrami 2007; Bense and Kurylyk 2017; Bense et al. 2017), soil temperature history, and effects of climate change (Kohl 1998; Balobaev et al. 2008; Herb et al. 2008; Stevens et al. 2008; Bayer et al. 2016).

Since the Chianan Plain is one of the most important groundwater regions in southern Taiwan, forty groundwater monitoring wells were installed within this area (Fig. 1). However, to date, no studies have focused on SST, land use surrounding monitoring wells, and temperature-depth profiles within the Chianan Plain. For understanding subsurface heat distributions and land temperature history and change, 
studying SST above monitoring well sites is necessary.

Temperature-depth profiles, SST measured data, and land cover percentage data are provided in this study. Relationships between SST and land cover types are also discussed. The temperature-depth profiles of the monitoring wells presented were measured from 2013 to 2019. A focus on the dataset obtained in 2015 is provided. Temperature data loggers were setup for collecting SST during 2017. The type and percentage of various land covers were determined using a small radius of $1 \mathrm{~m}$ and a larger radius of $100 \mathrm{~m}$ surrounding temperature data loggers or monitoring wells, identified using satellite images that were manually checked on site.

\section{STUDY AREA AND RESEARCH METHOD}

\subsection{Study Area}

The Chianan coastal plain is underlain by unconsolidated fine-grained interlayers of fluvial-deltaic deposits from the Pleistocene to a recent age (Lu et al. 2008). A hydrogeological cross-section indicated three aquifers from the surface to a depth of $200 \mathrm{~m}$ (Fig. 2). These aquifers largely consist of fine sand with mud layers, while aquitards consist of mud layers occasionally mixed with fine sand. According to C-14 dating, the age of sediments at approximately $200 \mathrm{~m}$ is $32 \mathrm{kyr}$ at well No. 14, located in the west

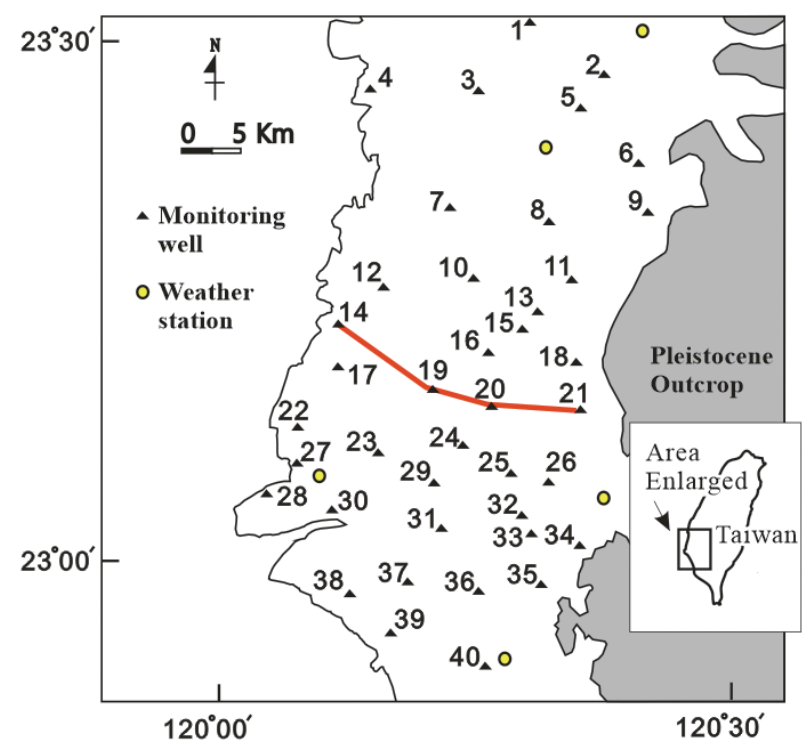

Fig. 1. Location of the Chianan Plain and groundwater monitoring wells. The red line indicates the location for the geological profile.

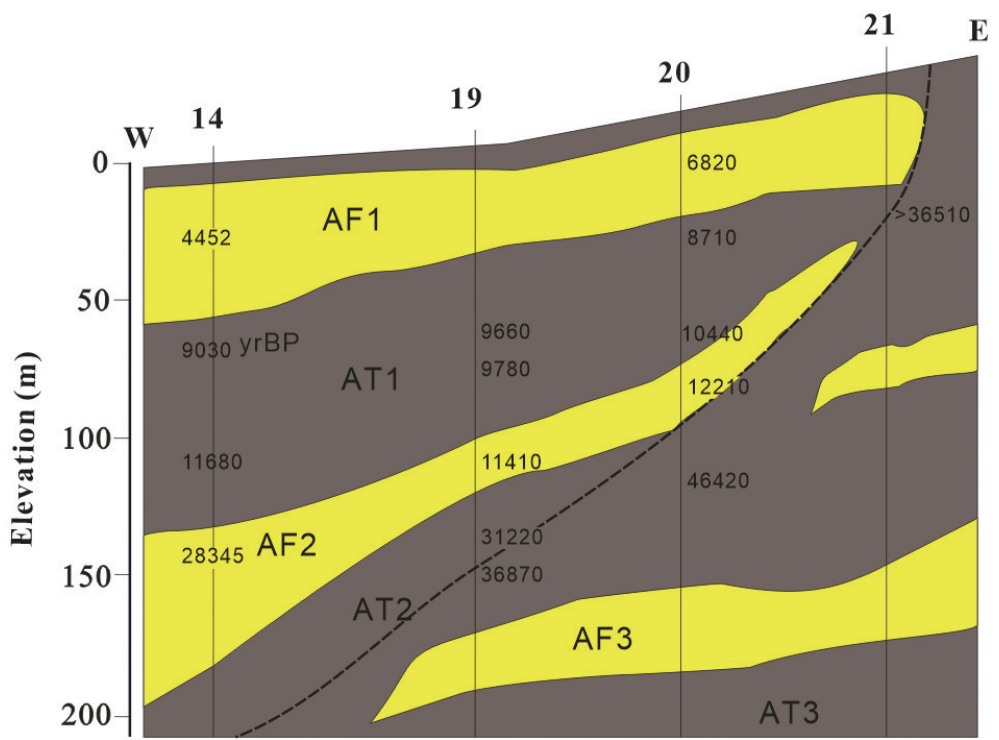

Fig. 2. The hydrogeological profile and the C-14 dating (yrBP) of sediments. AF1 indicates the first aquifer (yellow). AT1 is the first aquitard (brown). Lithology and dating data are from CGS (2018). 
near the coastline, while in the east, sediments of a similar age occur at shallower depths (CGS 2018).

From 1995 onward, a total of 40 monitoring wells have been installed within the Chianan Plain by the Water Resources Agency of Taiwan. The Chianan Plain has an area of approximately $75 \times 25 \mathrm{~km}^{2}$. Monitoring wells within the plain are constructed of stainless steel or polyvinyl chloride, are 10 to $15 \mathrm{~cm}$ in diameter, and have depths of 100 to 300 $\mathrm{m}$. Screens of 6 to $24 \mathrm{~m}$ in length were installed within the bottom portion of wells and are protected by a surface cement slab of 1 to $2 \mathrm{~m}$ in width (Lu et al. 2008).

\subsection{Research Method}

Three types of SST were utilized for the study. The first type is Measured Surface Soil Temperature (MSST), defined as the temperature measured using a data logger within the uppermost centimeters of the ground (Fig. 3c). The second and third types are the Present Surface Soil Temperature (PSST) and the Initial Surface Soil Temperature (ISST), estimated using temperature-depth profiles obtained from monitoring wells (Fig. 4). The PSST represents the long-term average (decade of year) temperature and the ISST indicates the temperature before human interference (Roy et al. 2002).

During 2017, temperature data loggers for collecting MSST, the Tidbit-v2-UTB1 from Hobo Onset Inc., were buried at 3 to $5 \mathrm{~cm}$ in depth below the soil surface over a horizontal distance to the well center of 2 to $4 \mathrm{~m}$ (Fig. 3c). The temperature data logger employed over an interval of $30 \mathrm{~min}$ has a working range of -20 to $70^{\circ} \mathrm{C}$, an accuracy of $\pm 0.2^{\circ} \mathrm{C}$, a resolution of $0.02^{\circ} \mathrm{C}$, and a maximum water pressure of $300 \mathrm{~m}$ (Helmuth et al. 2016).

Temperatures from data loggers within uppermost centimeters of the ground present a short distance of land cover affected SSTs, while temperature-depth curves at tens of meters in depth should be affected by larger distances of land cover. Two types of distance for land cover analysis were used. Land covers within a radius of $1 \mathrm{~m}$ surrounding data loggers were using for MSST and those at a radius of $100 \mathrm{~m}$ were used for PSST.

To differentiate between land cover types, areas were manually delineated using Google satellite images as a base map (Fig. 3a). Once an area of forest, a fish pond, grass, etc. was identified, land cover areas were categorized on an easy-to-analyze, color-coded map (Fig. 3b). To verify results, all land cover types surrounding monitoring wells within a radius of $100 \mathrm{~m}$ were manually checked on site using a GPS instrument (Fig. 3c).

Temperature-depth profiles were measured during 2013 to 2019 using an automatic probe attached to a polyethylene string placed at each measurement point over a vertical interval of $4 \mathrm{~m}$ for at least two minutes (at the first point for ten minutes) in order to ensure balance with borehole ambient temperatures (Fig. 4). Temperature data for the portion from the water level to the casing top were discarded. As a result of air's lower thermal diffusivity, temperatures were not in steady-state during the two minutes wait time (Eppelbaum et al. 2006). The probe employed for measurements, the Aqua TROLL 200 of In-Situ Inc., has a working range of -20 to $80^{\circ} \mathrm{C}$, an accuracy of $0.1{ }^{\circ} \mathrm{C}$, a resolution of $0.01^{\circ} \mathrm{C}$, and a maximum water pressure of $350 \mathrm{~m}$ (Chen and Chiang 2016).

Since the upper $20 \mathrm{~m}$ in temperatures were impacted by seasonal variation, values for PSST were estimated by extrapolation from the 20 to $50 \mathrm{~m}$ of the temperature-depth profiles. For example, the PSST of No. 14 was $27.39^{\circ} \mathrm{C}$ and was estimated using a second-degree polynomial fit. The value of $\mathrm{R}^{2}$ was 0.9987 (Fig. 5).

Under steady state conditions of no groundwater flow and constant surface temperature, the temperature-depth profile should be a straight line (e.g., No. 20 in the Fig. 4). However, some profiles indicate a warming (e.g., No. 14) upward trend. Profiles of well No. 14 displayed a straight line from 78 to $120 \mathrm{~m}$, located at the first aquitard (AT1), without significant groundwater flow (Fig. 4). Temperature differences from 78 to $120 \mathrm{~m}$ were small, less than $0.3^{\circ} \mathrm{C}$, from 2013 and 2019 (Fig. 6).

The initial SST (ISST) of well No. 14 was approximately $23.5^{\circ} \mathrm{C}$ using an extrapolation of a straight line from 78 to $120 \mathrm{~m}$. The ISST was interpreted as the temperature before the interference of surface temperature change or groundwater flow (Roy et al. 2002). The surface soil temperatures of well No. 14 displayed a $3.89^{\circ} \mathrm{C}$ warming trend from an ISST of 23.50 to the PSST of $27.39^{\circ} \mathrm{C}$.

\section{RESULTS AND DISCUSSION}

\subsection{Measured Surface Soil Temperature (MSST) and Land Cover}

MSST data were collected from a total of 40 monitoring sites during 2017. Data loggers at two sites, No. 4 and 11, were lost. In Table 1, the MSST from 38 monitoring sites are summarized by monthly and annual averages. The data indicate that the lowest annual MSST was $23.82^{\circ} \mathrm{C}$ (well No. 7) while the highest was $28.37^{\circ} \mathrm{C}$ (well No. 28), with an average of $25.83^{\circ} \mathrm{C}$ (Fig. 7a).

Land cover within a radius of $1 \mathrm{~m}$ surrounding data loggers were grouped into three types: trees, grass, and bare soil (Table 2). Twenty sites were under trees, thirteen sites were grass lands, and five sites were bare soil. Bare soil yielded the highest MSST, 26.02 to $28.37^{\circ} \mathrm{C}$, while trees yielded the lowest, 23.82 to $26.23^{\circ} \mathrm{C}$ (Fig. $7 \mathrm{~b}$ ). Compared to MSST, air temperatures from five weather stations within the study area (for locations see Fig. 1) were 23.93 to $25.29^{\circ} \mathrm{C}$, lower than bare soil.

The data are consistent with previous studies which concluded that land cover types of bare soil or pavement yield the highest SST due to solar radiation; whereas SST 
under trees, forests, and vegetated surfaces yield lower values (Herb et al. 2008).

\subsection{Present Surface Soil Temperature (PSST) and Land Cover}

Temperature-depth profiles for the 36 monitoring wells are plotted in Fig. 8. The depths of water level within the monitoring wells were 4 to $48 \mathrm{~m}$ and are referenced to the top of the well casing. Many of the temperature-depth profiles display a warming trend. Such subsurface temperature distribution may be due to land use change, global warming, or groundwater flow (Kohl 1999; Taniguchi et al. 1999, 2003; Huang et al. 2000; Pollack and Huang 2000; Ferguson et al. 2006; Bense and Beltrami 2007; Verdoya et al. 2007; Kataoka et al. 2009; Yamano et al. 2009; Bayer et al. 2016).

Values of PSST for each monitoring well were estimated by extrapolation from the temperature-depth profiles for 2015 (Table 3). The values of PSST ranged from 24.2 to $28.1^{\circ} \mathrm{C}$, with $80 \%$ of data falling within the range from 25 to $27^{\circ} \mathrm{C}$ (Fig. 9).

The types and percentages of land cover over a radius of $100 \mathrm{~m}$ surrounding monitoring wells were also determined. Five types of land cover were defined within the study area: trees, buildings, crops (grass), bare soil (pavement), and fish ponds (still water). The percentage of land cover type for each monitoring well is provided in Table 3.

Each type of land cover should contribute some per- centage of temperature to the surface and subsurface. Here, I present a simple empirical regression and correlation approach modified from Campbell et al. (1981). Calculated SSTs (CSSTs) were estimated using the empirical formula in Eq. (1):

$\mathrm{T}_{1} \mathrm{LC}_{1}+\mathrm{T}_{2} \mathrm{LC}_{2}+\mathrm{T}_{3} \mathrm{LC}_{3}+\mathrm{T}_{4} \mathrm{LC}_{4}+\mathrm{T}_{5} \mathrm{LC}_{5}=\mathrm{CSST}$

where $T_{1}, T_{2} \ldots T_{5}$ are the temperatures for each land cover type; and $\mathrm{LC}_{1}, \mathrm{LC}_{2} \ldots \mathrm{LC}_{5}$ are the percentages of each land cover type (Table 3 ).

Temperatures $T_{1}$ to $T_{5}$ are parameters that require estimation within the optimization problem. Using a range of temperatures (i.e., 23 to $29^{\circ} \mathrm{C}$ ) for different land cover types, MAE (mean absolute error) was determined using Eq. (2):

$\mathrm{MAE}=\boldsymbol{\Sigma}\left|\operatorname{PSST}_{\mathrm{n}}-\mathrm{CSST}_{\mathrm{n}}\right| / \mathrm{n}$

Values for PSST are provided in Table 3; $\mathrm{n}$ is the number of temperature-depth profiles. Using trial and error to determine the minimum MAE, temperatures were 24.9, 25.6, $25.6,26.5$, and $28.8^{\circ} \mathrm{C}$ for crops, trees, buildings, fish ponds, and bare soil, respectively, with a minimum MAE of $0.6^{\circ} \mathrm{C}$.

Both the PSST and MSST within the study area displayed a correlation to land cover type, which displayed a wide range of temperatures, 23 to $29^{\circ} \mathrm{C}$. Temperatures were
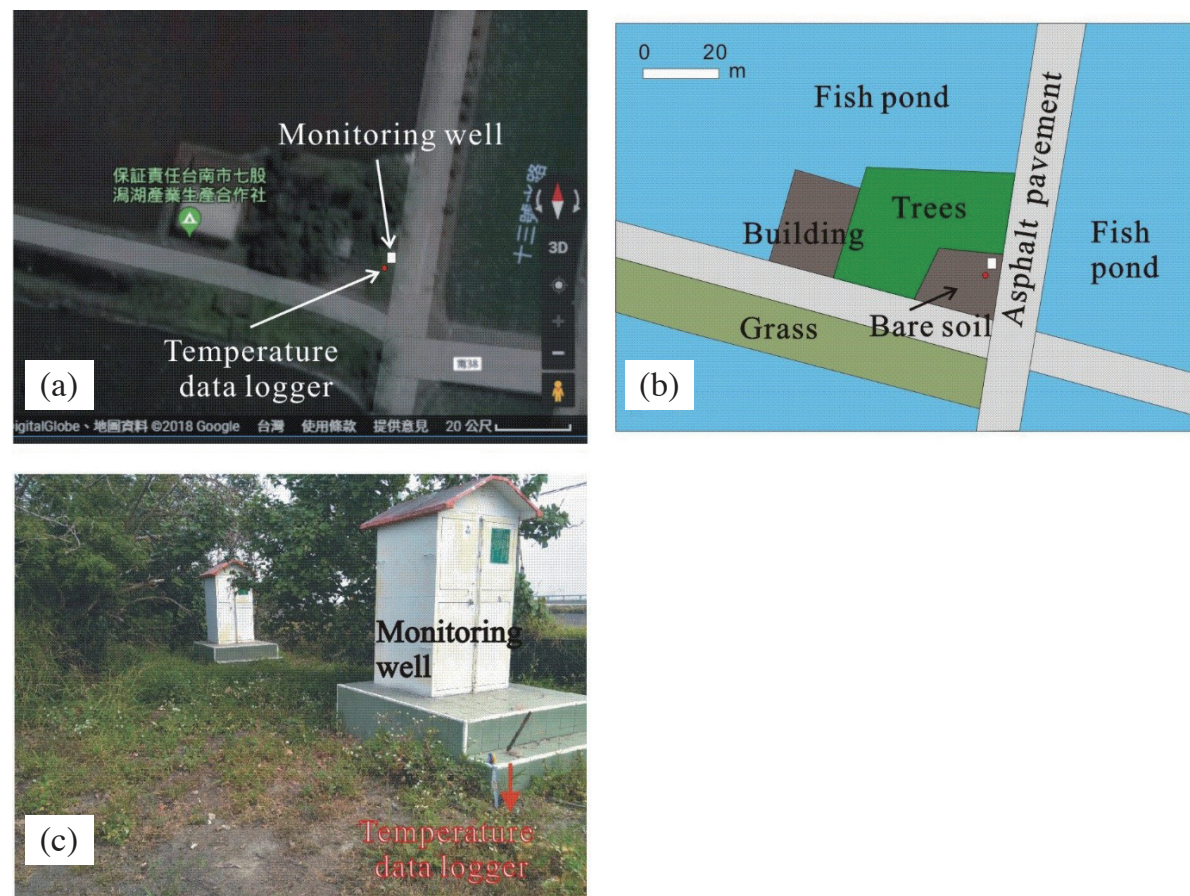

Fig. 3. (a) The location of monitoring well No. 28 within a Google map image. (b) Land cover types were manually identified based on a Google map image and an on-site check. (c) The photo displays monitoring wells, bare soil (with sparse grass), and trees (in the rear). The red arrow indicates the position of the temperature data logger. 


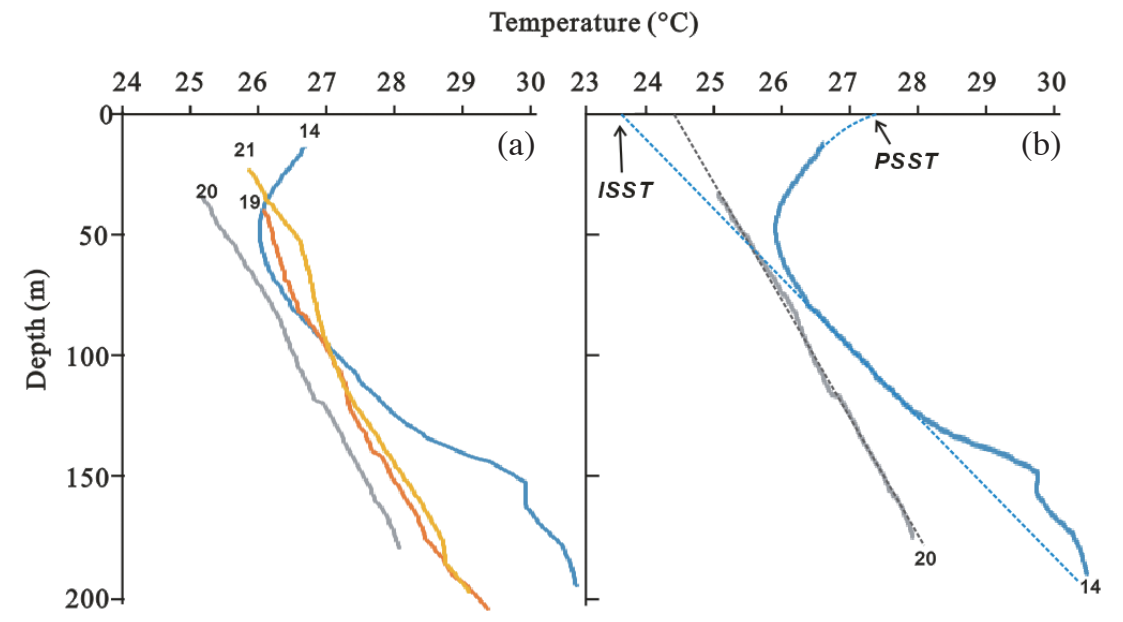

Fig. 4. (a) The temperature-depth profiles (January 2015) of four monitoring wells along the hydrogeological profile in Fig. 1. Numbers on the top of the lines are well IDs. (b) The PSST (present SST) and ISST (initial SST), extrapolated from the temperature-depth profile obtained from No. 14 (blue line). The straight dashed lines are assumed to be original temperature-depth profiles that were not affected by surface warming or groundwater flow.

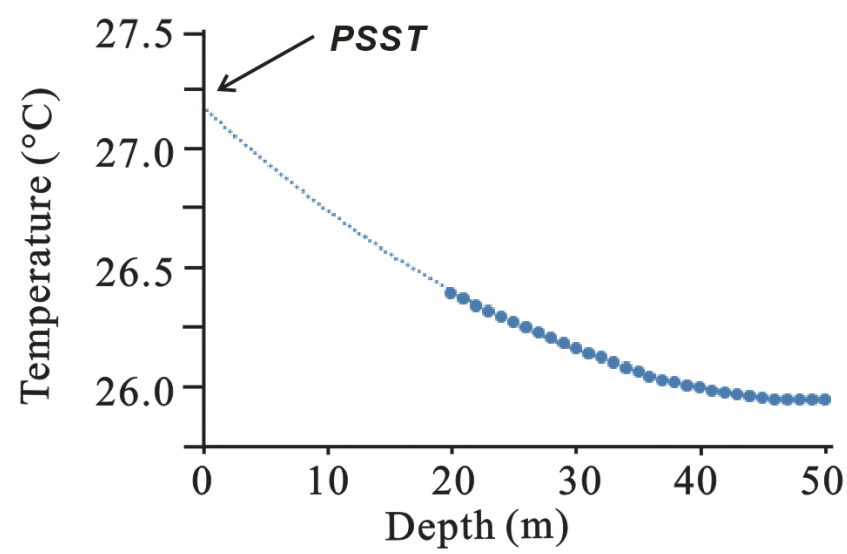

Fig. 5. The PSST, $27.39^{\circ} \mathrm{C}$, extrapolated from the 20 to $50 \mathrm{~m}$ portion of the temperature-depth profile of No. 14 by using a second-degree polynomial fitting with an $\mathrm{R}^{2}$ of 0.9987 . Larger dots indicate measured data and small dots indicate extrapolation.

(a) Temperature $\left({ }^{\circ} \mathrm{C}\right)$

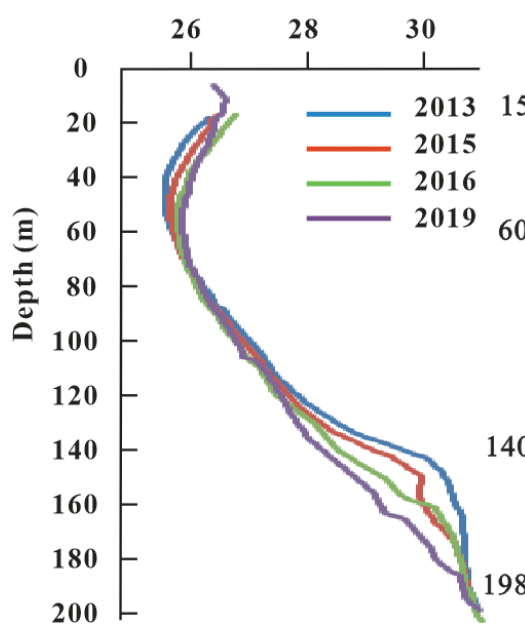

(b) $\Delta \mathbf{T}\left({ }^{\circ} \mathrm{C}\right) 2019-2013$

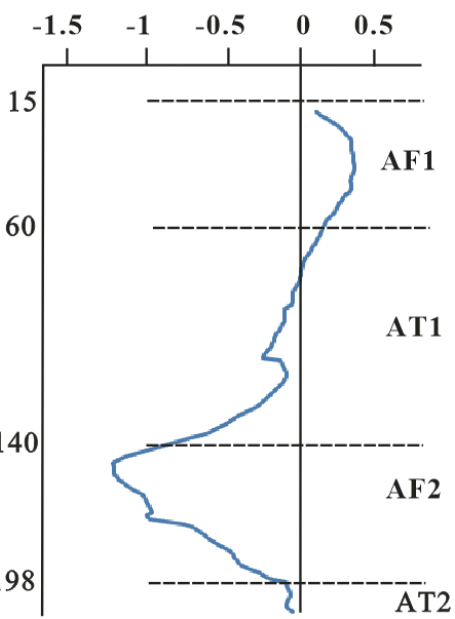

Fig. 6. (a) The temperature-depth profiles for No. 14 from 2013 to 2019. (b) Temperature differences between data from 2013 and 2019. 
Table 1. The MSST $\left({ }^{\circ} \mathrm{C}\right)$ of monitoring sites within the Chianan Plain during 2017.

\begin{tabular}{|c|c|c|c|c|c|c|c|c|c|c|c|c|c|}
\hline Well No & Jan & Feb & Mar & Apr & May & Jun & Jul & Aug & Sep & Oct & Nov & Dec & Average \\
\hline 1 & 19.00 & 19.21 & 21.29 & 24.30 & 26.56 & 28.22 & 28.41 & 28.99 & 29.90 & 26.46 & 23.41 & 19.32 & 24.59 \\
\hline 2 & 20.63 & 20.91 & 22.67 & 24.94 & 27.66 & 27.78 & 28.46 & 29.52 & 30.84 & 28.22 & 24.86 & 20.79 & 25.61 \\
\hline 3 & 18.06 & 18.16 & 21.78 & 24.78 & 27.62 & 28.84 & 29.42 & 29.92 & 28.87 & 25.78 & 22.63 & 17.73 & 24.47 \\
\hline 5 & 22.72 & 22.64 & 24.06 & 26.26 & 29.63 & 30.53 & 30.33 & 29.32 & 34.00 & 30.37 & 26.76 & 22.24 & 27.41 \\
\hline 6 & 19.01 & 19.26 & 21.93 & 24.01 & 26.09 & 27.11 & 27.28 & 27.97 & 28.66 & 25.97 & 23.36 & 19.58 & 24.19 \\
\hline 7 & 18.72 & 18.52 & 20.24 & 22.88 & 25.36 & 27.13 & 27.78 & 28.02 & 27.92 & 26.04 & 23.47 & 19.72 & 23.82 \\
\hline 8 & 19.07 & 19.62 & 21.87 & 24.84 & 30.27 & 30.02 & 31.15 & 31.03 & 31.19 & 28.55 & 24.35 & 20.29 & 26.02 \\
\hline 9 & 21.04 & 21.87 & 24.98 & 27.12 & 30.35 & 29.99 & 30.64 & 31.22 & 32.16 & 28.96 & 25.53 & 21.95 & 27.15 \\
\hline 10 & 19.13 & 19.98 & 23.09 & 25.72 & 28.37 & 29.78 & 30.71 & 30.83 & 30.88 & 28.31 & 24.83 & 21.09 & 26.06 \\
\hline 12 & 20.69 & 20.65 & 23.22 & 25.45 & 28.89 & 30.08 & 31.63 & 31.52 & 31.45 & 28.39 & 25.01 & 20.88 & 26.49 \\
\hline 13 & 19.20 & 19.51 & 21.94 & 25.30 & 27.11 & 27.88 & 28.12 & 28.57 & 28.73 & 27.32 & 24.38 & 21.77 & 24.99 \\
\hline 14 & 22.49 & 22.51 & 24.95 & 27.52 & 30.47 & 29.35 & 31.56 & 31.10 & 31.01 & 28.29 & 25.43 & 22.23 & 27.24 \\
\hline 15 & 18.22 & 19.78 & 24.86 & 27.61 & 31.25 & 31.47 & 31.46 & 31.38 & 31.63 & 27.91 & 24.02 & 19.64 & 26.60 \\
\hline 16 & 20.33 & 20.18 & 21.74 & 23.79 & 26.42 & 28.01 & 28.55 & 28.35 & 28.67 & 27.02 & 24.98 & 21.61 & 24.97 \\
\hline 17 & 19.52 & 19.94 & 22.00 & 24.00 & 27.21 & 28.48 & 30.01 & 29.73 & 30.19 & 27.5 & 24.03 & 19.73 & 25.20 \\
\hline 18 & 20.09 & 20.27 & 22.65 & 24.73 & 27.64 & 29.50 & 30.32 & 30.50 & 30.74 & 27.89 & 24.97 & 20.70 & 25.83 \\
\hline 19 & 20.70 & 21.09 & 24.06 & 26.70 & 30.25 & 30.45 & 31.56 & 31.52 & 31.83 & 29.73 & 26.69 & 22.54 & 27.26 \\
\hline 20 & 19.90 & 19.66 & 21.59 & 24.48 & 27.21 & 28.24 & 28.96 & 29.14 & 29.14 & 26.74 & 23.81 & 20.37 & 24.94 \\
\hline 21 & 18.16 & 18.64 & 21.30 & 25.05 & 28.59 & 29.66 & 30.27 & 30.00 & 28.9 & 26.47 & 23.18 & 19.13 & 24.95 \\
\hline 22 & 19.58 & 20.10 & 22.58 & 25.35 & 28.24 & 29.50 & 29.94 & 29.40 & 29.47 & 28.05 & 25.21 & 19.37 & 25.57 \\
\hline 23 & 21.51 & 21.2 & 23.6 & 26.09 & 29.76 & 30.38 & 31.41 & 31.01 & 30.80 & 28.40 & 25.75 & 21.82 & 26.82 \\
\hline 24 & 19.62 & 19.94 & 23.39 & 25.31 & 27.71 & 28.21 & 28.47 & 28.83 & 29.27 & 26.53 & 24.36 & 20.58 & 25.19 \\
\hline 25 & 19.84 & 20.14 & 21.70 & 24.13 & 27.34 & 28.08 & 28.62 & 28.24 & 28.93 & 26.58 & 24.23 & 20.84 & 24.89 \\
\hline 26 & 20.75 & 20.75 & 22.50 & 25.00 & 27.34 & 28.59 & 29.23 & 29.52 & 30.31 & 27.83 & 26.15 & 22.23 & 25.85 \\
\hline 27 & 18.77 & 19.21 & 22.26 & 25.28 & 28.30 & 30.20 & 31.10 & 31.43 & 31.30 & 27.92 & 25.04 & 18.61 & 25.79 \\
\hline 28 & 25.39 & 24.99 & 27.72 & 28.49 & 31.61 & 30.15 & 31.11 & 30.06 & 30.62 & 28.71 & 26.38 & 25.19 & 28.37 \\
\hline 29 & 22.06 & 22.78 & 25.00 & 27.50 & 29.34 & 30.83 & 31.45 & 31.13 & 30.99 & 28.56 & 25.68 & 21.94 & 27.27 \\
\hline 30 & 18.69 & 19.64 & 22.38 & 25.38 & 29.22 & 30.25 & 30.69 & 30.92 & 31.27 & 28.82 & 24.28 & 19.91 & 25.95 \\
\hline 31 & 19.81 & 20.14 & 23.00 & 26.00 & 28.42 & 29.82 & 30.34 & 30.21 & 30.00 & 27.20 & 23.95 & 19.74 & 25.72 \\
\hline 32 & 22.25 & 22.04 & 23.56 & 25.25 & 27.69 & 28.55 & 28.61 & 29.72 & 30.39 & 28.32 & 25.88 & 22.46 & 26.23 \\
\hline 33 & 20.89 & 21.11 & 23.97 & 26.38 & 28.13 & 28.03 & 27.86 & 28.96 & 29.91 & 26.88 & 24.95 & 20.98 & 25.67 \\
\hline 34 & 19.64 & 20.29 & 23.01 & 24.96 & 26.90 & 29.17 & 29.35 & 29.52 & 29.28 & 26.90 & 24.26 & 20.48 & 25.31 \\
\hline 35 & 19.06 & 19.73 & 23.05 & 26.08 & 28.85 & 29.93 & 29.82 & 29.82 & 29.25 & 26.88 & 23.98 & 20.05 & 25.54 \\
\hline 36 & 19.47 & 20.22 & 23.8 & 25.46 & 28.56 & 28.78 & 29.31 & 31.28 & 32.42 & 29.03 & 25.78 & 20.36 & 26.21 \\
\hline 37 & 20.29 & 20.34 & 22.58 & 24.62 & 27.91 & 28.72 & 29.24 & 29.75 & 30.15 & 28.43 & 25.24 & 21.02 & 25.69 \\
\hline 38 & 21.42 & 21.96 & 24.93 & 27.17 & 30.10 & 30.79 & 31.39 & 31.59 & 31.92 & 29.82 & 26.91 & 23.06 & 27.59 \\
\hline 39 & 18.33 & 18.43 & 20.66 & 24.25 & 27.91 & 28.75 & 29.58 & 29.90 & 29.20 & 27.14 & 23.75 & 19.83 & 24.81 \\
\hline 40 & 20.00 & 22.01 & 23.64 & 24.96 & 27.36 & 27.89 & 28.12 & 28.46 & 29.14 & 27.72 & 25.84 & 19.87 & 25.42 \\
\hline
\end{tabular}




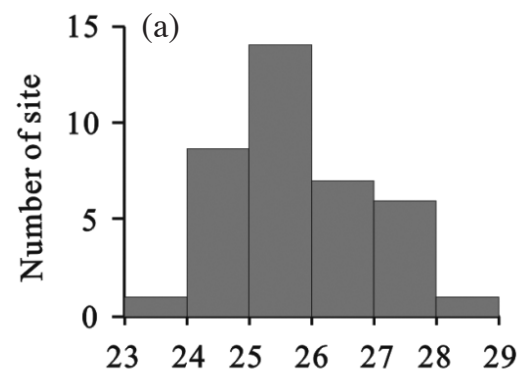

(b)

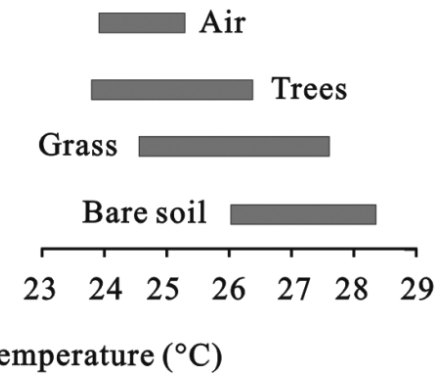

Fig. 7. (a) A histogram of MSST values for the 38 sites within the Chianan Plain during 2017. (b) Ranges of MSST values for the three land cover types and air temperatures in 2017. Data for air temperature were obtained from five weather stations maintained by the Central Weather Bureau, Taiwan.

Table 2. Types of land cover within a $1 \mathrm{~m}$ radius above data loggers.

\begin{tabular}{|c|c|c|c|c|c|c|c|}
\hline No & Land cover & No & Land cover & No & Land cover & No & Land cover \\
\hline 1 & Grass & 11 & Bare soil & 21 & Trees & 31 & Trees \\
\hline 2 & Trees & 12 & Bare soil & 22 & Grass & 32 & Trees \\
\hline 3 & Trees & 13 & Trees & 23 & Bare soil & 33 & Trees \\
\hline 4 & Grass & 14 & Bare soil & 24 & Grass & 34 & Trees \\
\hline 5 & Grass & 15 & Grass & 25 & Grass & 35 & Grass \\
\hline 6 & Trees & 16 & Trees & 26 & Trees & 36 & Trees \\
\hline 7 & Trees & 17 & Trees & 27 & Grass & 37 & Trees \\
\hline 8 & Bare soil & 18 & Trees & 28 & Bare soil & 38 & Grass \\
\hline 9 & Grass & 19 & Grass & 29 & Grass & 39 & Trees \\
\hline 10 & Grass & 20 & Trees & 30 & Trees & 40 & Trees \\
\hline
\end{tabular}

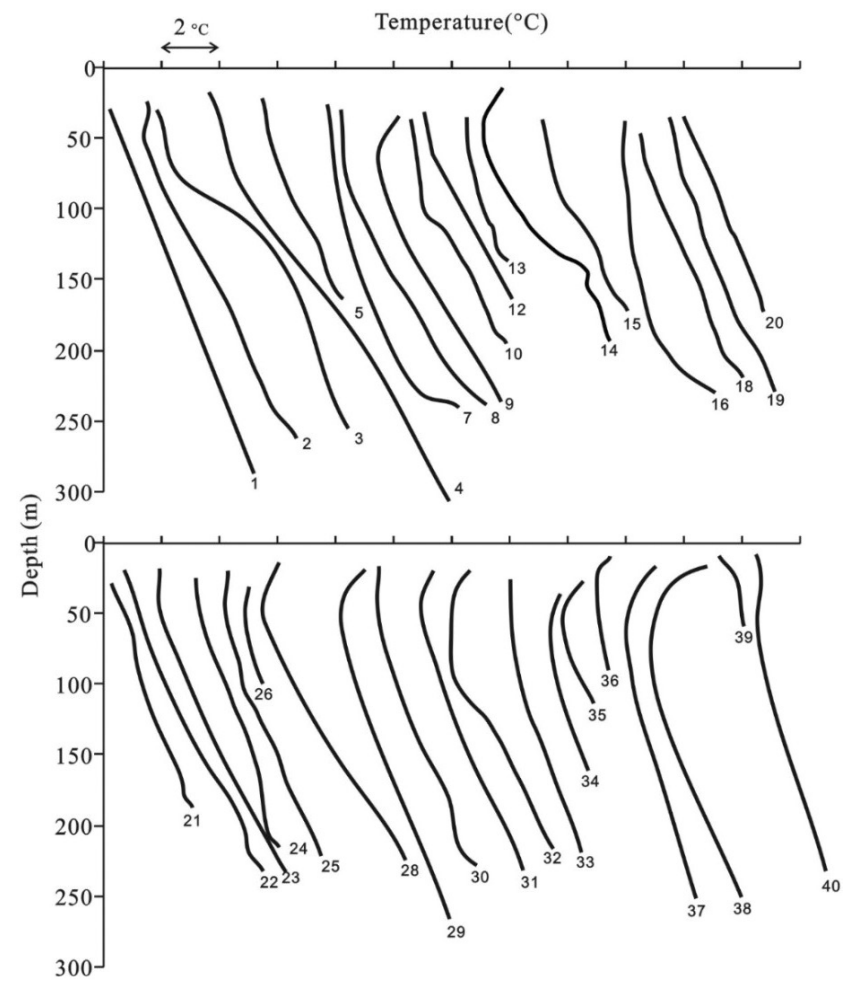

Fig. 8. Plots of the temperature-depth profiles obtained for 36 monitoring wells located within the Chianan Plain in 2015. Identification numbers corresponded to Fig. 1 and Table 1. Temperature-depth profiles were shifted to avoid overlap. 
Table 3. Percentages of land cover types over a radius of $100 \mathrm{~m}$ surrounding monitoring wells, PSST, CSST, and ISST.

\begin{tabular}{|c|c|c|c|c|c|c|c|c|}
\hline No & Trees $(\%)$ & Buildings (\%) & Crops (\%) & Bare soils (\%) & Fish ponds (\%) & $\operatorname{PSST}\left({ }^{\circ} \mathrm{C}\right)$ & $\operatorname{CSST}\left({ }^{\circ} \mathrm{C}\right)$ & ISST $\left({ }^{\circ} \mathrm{C}\right)$ \\
\hline 1 & 4 & 12 & 78 & 6 & 0 & 24.3 & 25.4 & 23.7 \\
\hline 2 & 11 & 9 & 62 & 18 & 0 & 25.6 & 25.7 & 24.3 \\
\hline 4 & 15 & 30 & 0 & 26 & 29 & 27.0 & 26.6 & 24.5 \\
\hline 5 & 0 & 0 & 85 & 15 & 0 & 25.3 & 25.6 & 24.5 \\
\hline 8 & 5 & 13 & 65 & 8 & 9 & 25.6 & 25.6 & 23.7 \\
\hline 9 & 24 & 59 & 0 & 18 & 0 & 27.1 & 26.4 & 24.1 \\
\hline 12 & 0 & 10 & 69 & 21 & 0 & 25.3 & 25.8 & 24.5 \\
\hline 13 & 6 & 60 & 0 & 34 & 0 & 26.6 & 26.5 & 25.3 \\
\hline 14 & 0 & 0 & 0 & 38 & 62 & 27.4 & 27.1 & 23.5 \\
\hline 15 & 19 & 21 & 52 & 8 & 0 & 25.0 & 25.6 & 24.4 \\
\hline 16 & 50 & 26 & 0 & 24 & 0 & 26.1 & 26.2 & 25.5 \\
\hline 18 & 7 & 62 & 3 & 28 & 0 & 24.2 & 26.3 & 24.5 \\
\hline 19 & 13 & 14 & 61 & 12 & 0 & 25.5 & 25.6 & 25.0 \\
\hline 20 & 81 & 11 & 0 & 8 & 0 & 24.5 & 25.8 & 24.5 \\
\hline 21 & 13 & 28 & 45 & 13 & 0 & 25.6 & 25.5 & 25.4 \\
\hline 22 & 9 & 22 & 40 & 29 & 0 & 25.8 & 26.1 & 25.4 \\
\hline 23 & 17 & 8 & 28 & 47 & 0 & 26.6 & 26.5 & 24.5 \\
\hline 24 & 22 & 61 & 8 & 10 & 0 & 25.7 & 26.2 & 24.8 \\
\hline 25 & 7 & 19 & 53 & 21 & 0 & 26.3 & 25.9 & 24.5 \\
\hline 26 & 14 & 34 & 40 & 12 & 0 & 26.7 & 25.8 & 25.2 \\
\hline 28 & 3 & 1 & 2 & 21 & 74 & 26.8 & 27.2 & 23.9 \\
\hline 29 & 8 & 14 & 52 & 27 & 0 & 28.1 & 26.2 & 24.1 \\
\hline 30 & 45 & 11 & 23 & 15 & 6 & 26.0 & 25.9 & 24.5 \\
\hline 31 & 0 & 25 & 48 & 27 & 0 & 26.8 & 26.0 & 24.7 \\
\hline 32 & 35 & 26 & 0 & 39 & 0 & 27.1 & 26.5 & 23.5 \\
\hline 33 & 8 & 42 & 0 & 50 & 0 & 25.6 & 26.7 & 24.3 \\
\hline 34 & 20 & 8 & 57 & 16 & 0 & 26.5 & 26.0 & 25.0 \\
\hline 35 & 14 & 14 & 49 & 22 & 0 & 27.2 & 25.6 & 25.4 \\
\hline 36 & 12 & 51 & 23 & 14 & 0 & 26.0 & 25.9 & 25.7 \\
\hline 37 & 20 & 17 & 15 & 42 & 7 & 28.1 & 26.8 & 24.7 \\
\hline 38 & 24 & 7 & 27 & 22 & 20 & 27.5 & 26.2 & 24.9 \\
\hline 39 & 6 & 77 & 0 & 16 & 0 & 25.8 & 25.9 & 25.8 \\
\hline 40 & 27 & 33 & 33 & 7 & 0 & 26.2 & 25.7 & 24.8 \\
\hline
\end{tabular}

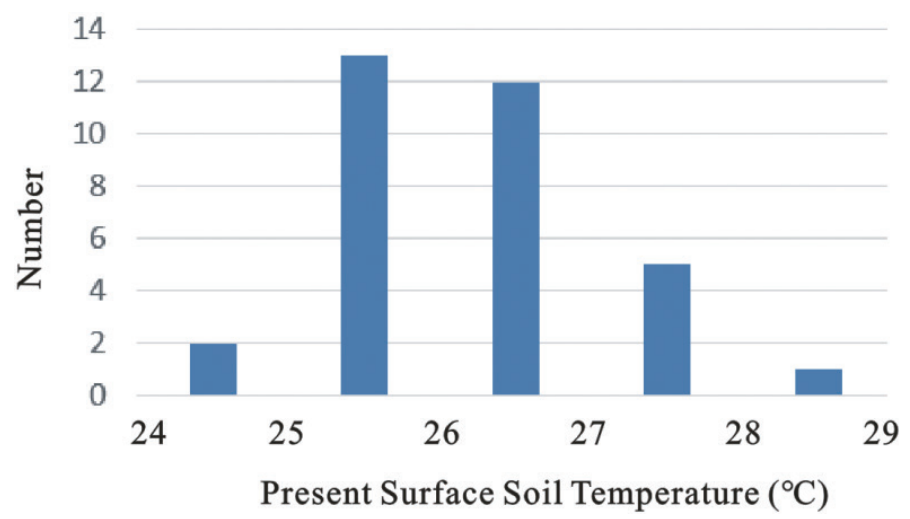

Fig. 9. A histogram of PSST estimated from the temperature-depth curves obtained from 36 monitoring wells in 2015. 
lower for shield land - crops, trees, and buildings. Temperatures were higher for no shield land - fish ponds and bare soil (pavement).

\subsection{Surface Soil Temperature Change and Land Cover Change}

Temperature-depth profiles are widely used for reconstructing historical surface temperature in association with climate change (Taniguchi et al. 1999; Pollack and Huang 2000; Roy et al. 2002; Eppelbaum et al. 2006; Balobaev et al. 2008; Ouzzaouit et al. 2014; Bayer et al. 2016). Surface soil temperature change can be obtained from PSST minus ISST which is estimated from temperature-depth profile. Data of PSSTs and ISSTs are listed in Table 3. Figure 10 shows the histogram of SST change determined from 2015 data. Values of SST change are in a range of -0.5 to $4.11^{\circ} \mathrm{C}$ with only two sites are negative (cooling). About $82 \%$ of sites have positive (warming) values in a range of 0 to $3^{\circ} \mathrm{C}$. The change of annual average air temperature worldwide due to global warming is approximately 1.0 to $2.0^{\circ} \mathrm{C}$ from 1901 to 2015 (Hsu et al. 2011; EPA 2016). Therefore, the cause for SST change larger than $2^{\circ} \mathrm{C}$ should be attributed to other mechanism in addition to global warming.

The SST change in the Chianan plain clearly shows a warming trend as interpreted from temperature-depth profiles. Previous studies indicated that surface temperature history inferred using temperature-depth profiles should consider the effect of land cover change and groundwater flow (Bense and Beltrami 2007; Bayer et al. 2016). This study demonstrates that surface soil temperatures within the Chianan Plain display a correlation to land cover over a range of temperatures, 23 to $29^{\circ} \mathrm{C}$. The SST could be changed for as much as $6^{\circ} \mathrm{C}$ while the land cover was changed from trees to bare soil.

Here, monitoring well No. 28 is used as an example for demonstrating that surface soil temperature may change partly due to land cover change. Changes in land use sur- rounding the monitoring wells are depicted from historical maps of 1904, 1924, 1956, and 1989 (Fig. 11). Those maps were obtained from an open web database called the Taiwan Centurial Historical Map archived by the Center for GIS, RCHSS, Academia Sinica (TCHM 2018). Well site No. 28 was located on a tidal flat as shown in maps of 1904 and 1924. From 1956 and 1989 maps, until the present day, the site is reclaimed land for fish ponds (Fig. 3). Land cover in the area is dominated by bare soils and fish ponds for 21 and $74 \%$, respectively (Table 3 ).

The initial surface soil temperature (ISST), extrapolated from the 60 to $200 \mathrm{~m}$ portion of the temperature-depth profile in 2015 , was approximately $23.9^{\circ} \mathrm{C}$ (Fig. 12). The PSST was $26.8^{\circ} \mathrm{C}$. The curve displays a warming trend from a depth of $60 \mathrm{~m}$, with the surface soil temperature increasing by $2.9^{\circ} \mathrm{C}$, larger than the global warming of $2.0^{\circ} \mathrm{C}$. Annual sea surface temperatures near the study area were 23.2 to $25.4^{\circ} \mathrm{C}$ (Belkin and Lee 2014), consistent with the ISST of $23.9^{\circ} \mathrm{C}$ from the study. Dominate land cover types at this site were fish ponds and bare land that display higher temperatures than the ISST. Calculated temperatures of this study for fish ponds and bare lands were 26.8 to $28.8^{\circ} \mathrm{C}$. The fish ponds at this site are growing milk fish. Previous study shows that growth and development were fastest in milk fish maintained in high test temperature $\overline{\mathrm{x}}=29.55^{\circ} \mathrm{C}$ (Villaluz and Unggui 1983). The SST of this site should be increased due to the land cover change from tidal flat to fish ponds. I suggest that the $2.9^{\circ} \mathrm{C}$ temperature increase was due to a land cover change from tidal flat to fish pond in addition to increasing temperature of global climate change.

\section{CONCLUSION}

Values for Measured Surface Soil Temperature (MSST) in 2017 were in a range of 23.8 to $28.3^{\circ} \mathrm{C}$, which are higher than the average annual air temperatures ranged from 23.9 to $25.2^{\circ} \mathrm{C}$ within the Chianan plain, southern Taiwan. The land cover types within a radius of $1 \mathrm{~m}$ around

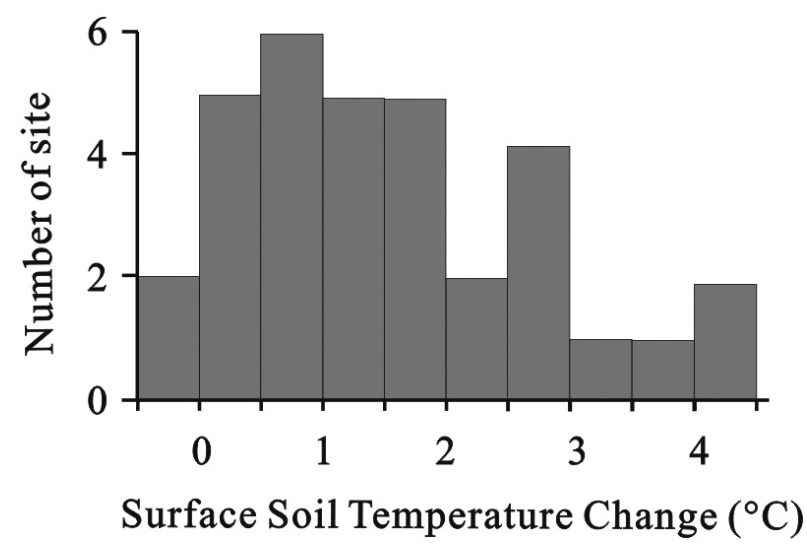

Fig. 10. A histogram of SST change (PSST minus ISST) estimated from the temperature-depth profiles obtained from monitoring wells in 2015. 

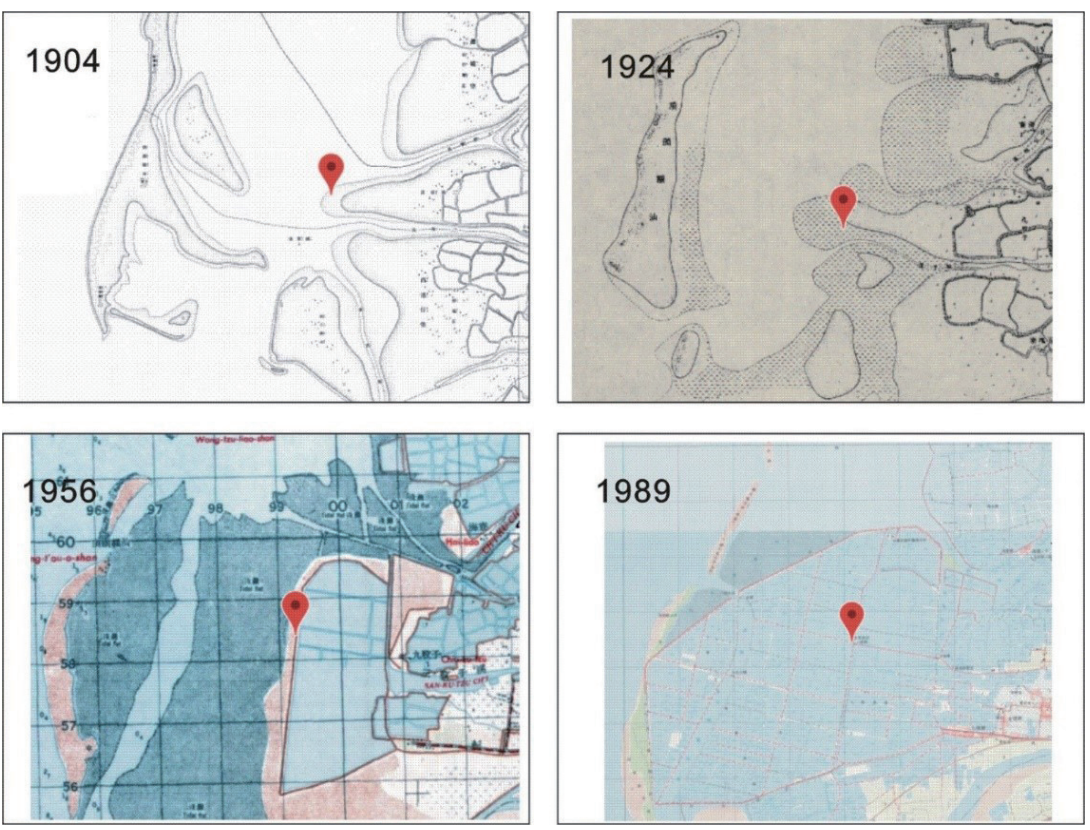

Fig. 11. The land cover change for monitoring well No. 28 (red mark) from 1904 to 1989. The well site was located on a tidal flat on maps from 1904 and 1924, while the site became reclaimed land for fish ponds in the 1956 and 1989 maps until the present day. The well was installed in 1995 (Fig. 3).

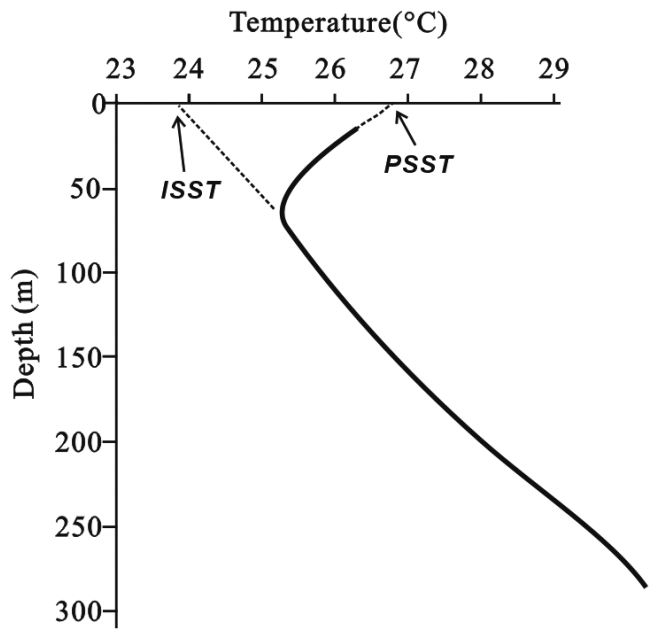

Fig. 12. The temperature-depth profile of well No. 28 during 2015. The ISST (Initial Surface Soil Temperature) is approximately $23.9^{\circ} \mathrm{C}$, extrapolated from the 60 to $200 \mathrm{~m}$ portion of the temperature-depth profile.

data loggers included: trees, grass, and bare soil. Temperatures for trees were lower than average while temperatures for bare soil without shielding were higher.

Values of Present Surface Soil Temperature (PSST) which represent a long term average were 24.2 to $28.1^{\circ} \mathrm{C}$, determined from temperature-depth profiles within Chianan plain in 2015. The PSSTs were correlated with percentages of a $100 \mathrm{~m}$ radius land cover area. Temperature of various land cover types were $24.9,25.6,25.6,26.5$, and $28.8^{\circ} \mathrm{C}$ for crops, trees, buildings, fish ponds, and bare soils, respectively.

Values of SST change, PSST minus ISST, show a warming trend with a maximum value of $4.11^{\circ} \mathrm{C}$ and $82 \%$ sites fall into a range of 0 to $3^{\circ} \mathrm{C}$ within Chianan plain. The change of annual average air temperature worldwide due to global warming is approximately 1 to $2^{\circ} \mathrm{C}$ during 1901 to 2015. The causes for SST change larger than $2^{\circ} \mathrm{C}$ should attribute to other mechanism in addition to global warming. For example, well No. 28 shows a $2.9^{\circ} \mathrm{C}$ temperature increasing which should due to a land cover change from tidal flat to fish pond in addition to global climate change.

This study provides the first basic data of MSST and temperature-depth profiles in the Chianan plain, southern 
Taiwan. Further studies for climate change, groundwater and subsurface temperature change in the Chianan plain can use the data as a base line.

Acknowledgements I thank the Ministry of Science and Technology of Taiwan, the Central Geological Survey, and the Water Resources Agency for research funding and support.

\section{REFERENCES}

Balobaev, V. T., I. M. Kutasov, and L. V. Eppelbaum, 2008: Borehole paleoclimatology - the effect of deep lakes and "heat islands" on temperature profiles. Clim. Past Discuss., 4, 415-432, doi: 10.5194/cpd-4-415-2008. [Link]

Bayer, P., J. A. Rivera, D. Schweizer, U. Schärli, P. Blum, and L. Rybach, 2016: Extracting past atmospheric warming and urban heating effects from borehole temperature profiles. Geothermics, 64, 289-299, doi: 10.1016/j.geothermics.2016.06.011. [Link]

Belkin, I. M. and M.-A. Lee, 2014: Long-term variability of sea surface temperature in Taiwan Strait. Clim. Change, 124, 821-834, doi: 10.1007/s10584-0141121-4. [Link]

Bense, V. F. and H. Beltrami, 2007: Impact of horizontal groundwater flow and localized deforestation on the development of shallow temperature anomalies. J. Geophys. Res., 112, doi: 10.1029/2006JF000703. [Link]

Bense, V. F. and B. L. Kurylyk, 2017: Tracking the subsurface signal of decadal climate warming to quantify vertical groundwater flow rates. Geophys. Res. Lett., 44, 12244-12253, doi: 10.1002/2017gl076015. [Link]

Bense, V.F., B. L. Kurylyk, J. van Daal, M. J. van der Ploeg, and S. K. Carey, 2017: Interpreting repeated temperature-depth profiles for groundwater flow. Water Resour. Res., 53, 8639-8647, doi: 10.1002/2017wr021496. [Link]

Campbell, C. A., W. Nicholaichuk, V. O. Biederbeck, H. Ukrainetz, and J. Bole, 1981: An empirical method of estimating soil temperature on cropped land on $\mathrm{Ca}$ nadian prairies. Can. J. Plant Sci., 61, 565-573, doi: 10.4141/cjps81-079. [Link]

CGS (Central Geological Survey of Taiwan), 2018: Hydrogeological database. Available at https://hydro.moeacgs.gov.tw/plain.

Chen, W. and H. Chiang, 2016: Subsurface temperature trends in response to thermal water exploitation in the Jiashi Hot Spring, northeastern Taiwan. Geothermics, 60, 126-133, doi: 10.1016/j.geothermics.2015.12.007. [Link]

Deardorff, J. W., 1978: Efficient prediction of ground surface temperature and moisture, with inclusion of a layer of vegetation. J. Geophys. Res., 83, 1889-1903, doi: 10.1029/jc083ic04p01889. [Link]

EPA, 2016: U.S. and Global Temperature. Climate Change Indicators in the United States, Fourth Edition, EPA 430-R-16-004, United States Environmental Protection Agency, 18-19. Available at https://www.epa.gov/ climate-indicators.

Eppelbaum, L. V., I. M. Kutasov, and G. Barak, 2006: Ground surface temperature histories inferred from 15 boreholes temperature profiles: Comparison of two approaches. Earth Sci. Res. J., 10, 25-34.

Ferguson, G., H. Beltrami, and A. D. Woodbury, 2006: Perturbation of ground surface temperature reconstructions by groundwater flow? Geophys. Res. Lett., 33, doi: 10.1029/2006GL026634. [Link]

Helmuth, B., F. Choi, A. Matzelle, J. L. Torossian, S. L. Morello, K. A. S. Mislan, L. Yamane, D. Strickland, P. L. Szathmary, S. E. Gilman, A. Tockstein, T. J. Hilbish, M. T. Burrows, A. M. Power, E. Gosling, N. Mieszkowska, C. D. G. Harley, M. Nishizaki, E. Carrington, B. Menge, L. Petes, M. M. Foley, A. Johnson, M. Poole, M. M. Noble, E. L. Richmond, M. Robart, J. Robinson, J. Sapp, J. Sones, B. R. Broitman, M. W. Denny, K. J. Mach, L. P. Miller, M. O'Donnell, P. Ross, G. E. Hofmann, M. Zippay, C. Blanchette, J. A. Macfarlan, E. Carpizo-Ituarte, B. Ruttenberg, C. E. Peña Mejía, C. D. McQuaid, J. Lathlean, C. J. Monaco, K. R. Nicastro, and G. Zardi, 2016: Long-term, high frequency in situ measurements of intertidal mussel bed temperatures using biomimetic sensors. Scientific Data, 3, 160087, doi: 10.1038/sdata.2016.87. [Link]

Herb, W. R., B. Janke, O. Mohseni, and H. G. Stefan, 2008: Ground surface temperature simulation for different land covers. J. Hydrol., 356, 327-343, doi: 10.1016/j. jhydrol.2008.04.020. [Link]

Holmes, T. R. H., T. J. Jackson, R. H. Reichle, and J. B. Basara, 2012: An assessment of surface soil temperature products from numerical weather prediction models using ground-based measurements. Water Resour. Res., 48, doi: 10.1029/2011WR010538. [Link]

Hsu, H. H., C. Chou, Y. C. Wu, M. M. Lu, C. T. Chen, and Y. M. Chen, 2011: Climate Change in Taiwan: Scientific Report 2011 (Summary), National Science Council, Taipei, Taiwan, $67 \mathrm{pp}$.

Huang, S., H. N. Pollack, and P.-Y. Shen, 2000: Temperature trends over the past five centuries reconstructed from borehole temperatures. Nature, 403, 756-758, doi: 10.1038/35001556. [Link]

Kataoka, K., F. Matsumoto, T. Ichinose, and M. Taniguchi, 2009: Urban warming trends in several large Asian cities over the last 100 years. Sci. Total Environ., 407, 3112-3119, doi: 10.1016/j.scitotenv.2008.09.015. [Link]

Kohl, T., 1998: Palaeoclimatic temperature signals - Can they be washed out? Tectonophysics, 291, 225-234, 
doi: 10.1016/s0040-1951(98)00042-0. [Link]

Kohl, T., 1999: Transient thermal effects below complex topographies. Tectonophysics, 306, 311-324, doi: 10.1016/s0040-1951(99)00063-3. [Link]

Kupfersberger, H., G. Rock, and J. C. Draxler, 2017: Inferring near surface soil temperature time series from different land uses to quantify the variation of heat fluxes into a shallow aquifer in Austria. J. Hydrol., 552, 564577, doi: 10.1016/j.jhydrol.2017.07.030. [Link]

Leaf, J. S. and E. Erell, 2018: A model of the ground surface temperature for micrometeorological analysis. Theor. Appl. Climatol., 133, 697-710, doi: 10.1007/s00704017-2207-5. [Link]

Lu, H.-Y., T.-K. Liu, W.-F. Chen, T.-R. Peng, C.-H. Wang, M.-H. Tsai, and T.-S. Liou, 2008: Use of geochemical modeling to evaluate the hydraulic connection of aquifers: A case study from Chianan Plain, Taiwan. Hydrogeol. J., 16, 139-154, doi: 10.1007/s10040-0070209-6. [Link]

Lundquist, J. D. and F. Lott, 2008: Using inexpensive temperature sensors to monitor the duration and heterogeneity of snow-covered areas. Water Resour. Res., 44, doi: 10.1029/2008WR007035. [Link]

Ouzzaouit, L. A., A. Bakraoui, N. Benalioulhaj, J. Carneiro, A. Correia, A. Jilali, A. Rimi, and Y. Zarhloule, 2014: Recent warming trends inferred from borehole temperature data in Figuig area (Eastern Morocco). J. Afr. Earth Sci., 96, 1-7, doi: 10.1016/j. jafrearsci.2014.03.002. [Link]

Pollack, H. N. and S. Huang, 2000: Climate reconstruction from subsurface temperatures. Annu. Rev. Earth Planet. Sci., 28, 339-365, doi: 10.1146/annurev. earth.28.1.339. [Link]

Roy, S., R. N. Harris, R. U. M. Rao, and D. S. Chapman, 2002: Climate change in India inferred from geothermal observations. J. Geophys. Res., 107, ETG 5-1ETG 5-16, doi: 10.1029/2001jb000536. [Link]

Shafer, M. A., C. A. Fiebrich, D. S. Arndt, S. E. Fredrickson, and T. W. Hughes, 2000: Quality assurance procedures in the Oklahoma Mesonetwork. J. Atmos. Oceanic Technol., 17, 474-494, doi: 10.1175/1520-0426(2000)017<0474:QAPITO>2.0. CO;2. [Link]

Signorelli, S. and T. Kohl, 2004: Regional ground surface temperature mapping from meteorological data. Global Planet. Change, 40, 267-284, doi: 10.1016/j.gloplacha.2003.08.003. [Link]

Skinner, W. R. and J. A. Majorowicz, 1999: Regional cli- matic warming and associated twentieth century landcover changes in north-western North America. Clim. Res., 12, 39-52, doi: 10.3354/cr012039. [Link]

Smirnova, T. G., J. M. Brown, and S. G. Benjamin, 1997: Performance of different soil model configurations in simulating ground surface temperature and surface fluxes. Mon. Weather Rev., 125, 1870-1884, doi: 10.1175/1520-0493(1997)125<1870:PODSMC >2.0. $\mathrm{CO} ; 2 .[\underline{\mathrm{Link}}]$

Stevens, M. B., J. F. González-Rouco, and H. Beltrami, 2008: North American climate of the last millennium: Underground temperatures and model comparison. J. Geophys. Res., 113, doi: 10.1029/2006JF000705. [Link]

Taniguchi, M., J. Shimada, T. Tanaka, I. Kayane, Y. Sakura, Y. Shimano, S. Dapaah-Siakwan, and S. Kawashima, 1999: Disturbances of temperature-depth profiles due to surface climate change and subsurface water flow: 1. An effect of linear increase in surface temperature caused by global warming and urbanization in the Tokyo metropolitan area, Japan. Water Resour. Res., 35, 1507-1517, doi: 10.1029/1999wr900009. [Link]

Taniguchi, M., J. Shimada, and T. Uemura, 2003: Transient effects of surface temperature and groundwater flow on subsurface temperature in Kumamoto Plain, Japan. Phys. Chem. Earth, 28, 477-486, doi: 10.1016/s14747065(03)00067-6. [Link]

TCHM, 2018: Taiwan Centurial Historical Map, Center for GIS, RCHSS, Academia Sinica, Taipei, Taiwan. Available at http://gis.rchss.sinica.edu.tw/.

Vargo, J., D. Habeeb, and B. Stone, 2013: The importance of land cover change across urban-rural typologies for climate modeling. J. Environ. Manage., 114, 243-252, doi: 10.1016/j.jenvman.2012.10.007. [Link]

Verdoya, M., P. Chiozzi, and V. Pasquale, 2007: Thermal $\log$ analysis for recognition of ground surface temperature change and water movements. Clim. Past, 3, 315324, doi: 10.5194/cp-3-315-2007. [Link]

Villaluz, A. C. and A. Unggui, 1983: Effects of temperature on behavior, growth, development and survival in young milkfish, Chanos chanos (Forskal). Aquaculture, 35, 321-330, doi: 10.1016/0044-8486(83)901047. [Link]

Yamano, M., S. Goto, A. Miyakoshi, H. Hamamoto, R. F. Lubis, V. Monyrath, and M. Taniguchi, 2009: Reconstruction of the thermal environment evolution in urban areas from underground temperature distribution. Sci. Total Environ., 407, 3120-3128, doi: 10.1016/j. scitotenv.2008.11.019. [Link] 